\title{
A Computerized Approach towards Centralization of National Identity and Its Aspect in Forensic Practice - Aadhar Card
}

\author{
Amit Chauhan* and Kumkum Singh \\ Amity Institute of Forensic Sciences, Amity University, India
}

Submission: November 08, 2017; Published: November 22, 2017

*Corresponding author: Amit Chauhan, Amity Institute of Forensic Sciences, Amity University sec-125 (Noida), Uttar Pradesh, India, Tel: 91-9540067484; Email: amit_chauhan777@yahoo.in

\begin{abstract}
With the inflating rate of crime in our society, the advancement in investigating techniques has become a necessity in our society. Personal information of an individual is being digitalized at national as well as international level which could be used to prove the identity. Now a day, numerous perpetual and unique identity features i.e. Retina, fingerprint Metrix system, palm prints, voice identification are being utilized by the security agencies to secure the personal data. Aadhar card is a very important initiative taken by the Government of India to digitalize the personal data of an individual to secure in form of unique identity in 12 numerical values. Aadhar card is issued by the Unique Identification Authority of India after its records are verified with the details of every Indian citizen including biometric and demographic data. This individualized information could be beneficial for investigating agencies during the crime scene investigation and to expose the identity of suspect. If the personal data of an individual (Aadhar card) could be centralized, then it will be a great achievement for law enforcement agencies to nab the suspect and put them behind the bar.
\end{abstract}

Keywords: Identity; Suspect; Forensic practice; Investigation; Crime scene

\section{Introduction}

In the present scenario, the national security has become an enormous issue for every nation. The ever-increasing rate of crime in our society demands the advancement and digital approach towards the establishment the identity of suspects/ culprits. To secure the nation and provide the security to its citizen, every country is centralizing its citizen's unique identity digital data in form of various forms i.e. Metrix system, retina scanning, voice identification. The Indian Government took imitative towards to provide the universal digital identity to every citizen. In 2009, Aadhar card was launched with a detachment to provide the digital data to the identity of its citizen but due to a few of difficulties such as technical snags, incorrect data display raised a question against its importance [1]. Again in 2014, this program was started again with many of resolved issues and ease in its acceptance. Aadhar card was an attempt to uniquely and digitally identify people from the purpose to track the social security of an individual. This program was inspired by the social security number issued by a few of countries i.e. USA, china etc. but conceptually, Aadhar is supposed to benefit of social inclusion on all development parameters and pitched as more than an identity card [2].

In extension to this, it helps in reducing the corruption since every individual carry only unique identity number. Now a day, it has become a necessity to connect every document such as bank account, domestic supply (gas connection), passport, digital locker, mobile sim card, voter card etc. with the Aadhar cards that not only increase the security of an individual but also, prevent from fraudulent and make it easy to do the things within a short latency time. Since 2017, Indian Government has made it mandatory to connect the aadhar card with every social aspect of usage [3]. In a few of the issues, public distribution system is one which require social security measure which is related to the unique identity of a person and helps to claim the identity of a person who migrate from one place to another and prevent the corruption in subsidized supplies such as food, kerosene etc. Financial inclusion is another issue in which the banks don't have any incentive to create and manage the accounts for people with insignificant income especially in case of a migrant. Some aspects such as direct cash transfer, food security, employment are some large scale public schemes that could be better managed by using this unique id and everyone could be benefited from it [4].

\section{Asset of Aadhar Card}

Aadhar card is a universal biometric card that stores an individual's personal details in a government database which is fast becoming the government base for public welfare. It is used for a number of purpose and being centralized it can 
distribute and keep track of the various schemes provide by the government. Acquisition of passport is a daunting endeavor which requires plenty of time in the process of application, verification checks by law enforcement agencies. Now, it will be possible within 10 days from Aadhar card and police verification can be scheduled at later. Other assets such as opening a bank account, digital life certificate has become easier in which only UID is required along with a passport size photo [5]. Receipt of monthly pension and disbursing the provident fund to retired government employees that timely pension can be received. Any Government scheme such as Jan Dhan Yojna that is to offer considerable help to people in remote and rural areas to avail the services [6]. It is direct based on benefit transferred by the kitchen gas subsidy wherein the distributor for any particular area. It is very ease to access to carry it anywhere anytime in form of digital e copy which is available in download version whenever and wherever is require. Now, according to the latest update of aadhar card it has been made mandatory for most and day to day activities i.e. Mobile number should relate to aadhar card, driving license, PAN card, IT return [7].

\section{Aspects of Aadhar Card In Forensic Practice}

With the increasing rate of crime in our society, new techniques of investigations are emerging rapidly towards the less latency time and conclusive identification of an individual. A numerous forms of evidences are encountered from the scene of occurrence which plays a vital role to establish the identity of suspect. In all the evidences, Fingerprints are considered unique, perpetual and universal of every individual like DNAfingerprints. These prints are encountered in several conditions such as latent prints, semi-visible, plastic and patent prints in form of the few ridges present at surfaces/ objects or at the entry of exit which provides the information about an individual i.e. gender, age etc. If these fingerprints ridge details could intensify at scene of occurrence and could directly connected from the UID (Aadhar Card), the information about the suspect such as address, name, age and gender can gather immediately. It will prove a great helping hand for the investigators/ law enforcement agencies to nab the suspect within a few latency times after the commencement. This centralized system of aadhar card will be able to provide the information about the terrorist involve in an anti-national activity. In cases of sexual harassment, rape etc. the fingerprints are found over the different body parts of the victim including other biological evidences; can be left by using fluorescence powder and lifting techniques. If the victim is dead in those cases, the hard x-ray can be used for intensification of fingerprints and information about the suspect/ culprit can be gathered from it. Whereas, the examination of biological samples and their analysis will take much time rather than the procedure which will require only a few of minutes. In cases of murder/ attempt to murder, burglary, the struggle marks in form of the fingerprints present at front part of body can be recovered and matched with the data of aadhar card.
In other prospects of forensic science, questioned documents examination field is very important to prove the authenticity of the documents and to identify the author/suspect of it. These documents are encountered in numerous forms such as disputed, forged or copied by other persons and hence a question rose against its authenticity. It may include valuable documents i.e. power of attorney, will, authority letter, important secret official files, leak defense documents, bank documents, suicide notes, drawings etc. where the identification can be done by using the analysis process of questioned documents but it will be time taking. But it could be an ease access to get the information about the actual person by using the UID. It is considered the when a person writes or draw something, nobody can help them to hold the pen or to facilitate the movement of hand or to write, in those cases, the touch of their fingerprints at writing surface left their identity in form of latent fingerprints. If these latent fingerprints could be intensified from the paper and matched with the available data of aadhar card, it will immediately reveal the identity of the culprit/ victim. The culprit could be nabbed before their commencement in any other crime.

During the examination of any firearm or weapon of offence, the fingerprints which will be present at the magazine of firearm, barrel, trigger, handle of weapon, safety pin lock etc. could be intensified easily. When these intensified fingerprints will be scanned at UID, the identity of culprit will be revealed within a few of second. Since so long in a few of the cases, it is claimed that the evidences have changed in the forensic laboratory which was handed over for analysis. During the handling of evidences, audio video evidences, cybercrime, mobile etc., a procedure of information about investigating officer, name of handling officer, designation etc. are noticed yet the questioned raised against the authenticity of evidences that can be proved easily from with the help of UID if it was exchanged/ disputed. In this process, the fingerprints present on the envelope can be easily intensify and the people those who were involved in that act could be caught. Now a day in cases of mobile crime such as murder, rape or kidnapping, vehicle is frequently used to move from one place to another. In these cases, the identity of the vehicles is hiding either by changing their number plate or colour, by providing a few of modification and are found heirless condition from the road side/ forest and the identity of vehicle remain in question. The identity of the culprits/ owner can be done by collecting their fingerprints from the steering of vehicle/ handle of the gate of vehicle, inner lock, window etc. After a requirement of intensification, these fingerprints could be scanned from the UID data and identity with full details will be revealed at the screen within a few of seconds.

\section{Conclusion}

As per the latest information, the supreme court of India has ordered that the government cannot be stopped from using the aadhar card for its non-welfare schemes like opening of bank accounts, verification of existing and new mobile phone 
numbers and other user credentials etc. However, it did maintain that the government cannot make Aadhar mandatory for welfare schemes and it has allowed the government to use it in some schemes, not permitted to be used as a mandatory requirement that must be. Once the UID completion work will be over, it must be centralized and authorized for the access to the investigation agencies so that at the time of instances, it could be utilized by them to nab the suspect/ culprits/ anti-national activists. This facility will not help to nab the culprits but will also help to prevent their involvement in the other illegal commencement. The crime rates will decrease instantly and will also protect the right to be provided to the Indian citizens who are lacking by this time because of the entry of refugees and other people who easily get access in India. Aadhar card with some modification in its system might be proven one of the best technologies for individuality in the world.

\section{References}

1. Scroll.in (2017) Privacy, security and legality are not the only serious problems with Aadhar. Here are more. Wednesday, $8^{\text {th }}$ November 2017.

2. Businesstoday.in (2017) Aadhar privacy; Key issues that all aadhar card holders should bear in mind. $19^{\text {th }}$ July 2017.

3. Allonmoney.com (2015) 17 benefits of aadhar card, why it is mandatory, important uses. $8^{\text {th }}$ March 2015.

4. Bankbazar.com (2016) Benefits of Aadhar card. 28 $8^{\text {th }}$ December 2016.

5. Tomorrow makers (2017) 7 benefits of aadhar Card. $20^{\text {th }}$ September 2017.

6. The Economic Times (2017) 7 benefits of Aadhar Card. 28 ${ }^{\text {th }}$ April 2017.

7. The Indian Express (2017) What is aadhar card and where is it mandatory? 27 $7^{\text {th }}$ March 2017.

Your next submission with Juniper Publishers will reach you the below assets

- Quality Editorial service

- Swift Peer Review

- Reprints availability

- E-prints Service

- Manuscript Podcast for convenient understanding

- Global attainment for your research

- Manuscript accessibility in different formats

( Pdf, E-pub, Full Text, Audio)

- Unceasing customer service

Track the below URL for one-step submission https://juniperpublishers.com/online-submission.php 